\title{
Effect of Technology Adoption on New Product Innovation
}

T. Joseph Musandiwa

University of Limpopo, South Africa

joseph.musandiwa@ul.ac.za

Collins C. Ngwakwe

University of Limpopo, South Africa

collins.ngwakwe@ul.ac.za

This paper examines the effect of licensing of foreign technology on new product innovation and market access. Data were collected from the archives of the World Bank's Global Enterprises Survey for fifty countries. The data were analysed using the Structural Equation Model (SEM) with the aid of STATA software. The SEM result show that licensing of external technology is positively and significantly related to new product innovation and access to market. However, the moderating independent variable (website usage) did not show a significant relationship with new product innovation and market access. The paper offers practical implication for new product innovation, which is that local enterprises can save the internal cost and time of research and development for new products by adopting the option of licensing foreign technology. This also has the advantage of assisting local enterprises to offer a new product to the market. Further research is recommended to add more countries to increase the number of observations.

Key Words: technology adoption, product innovation, foreign technology, technology licensing

JEL Classification: 032, O3, O31, 033, L6, M11

https://doi.org/10.26493/1854-6935.18.177-194

\section{Introduction}

Enterprise product innovation involves much time and cost of internal research and development (R\&D) (Evangelista et al. 1998). Yet innovation is a vital competitive strategy to remain resilient in a dynamic global business environment (Salunke, Weerawardena, and McColl-Kennedy 2019). Given the cost and time of engaging in internal R\&D (Schuhmacher et al. 2018), some enterprises lag behind the fast changing technology with attendant loss of market niche. Therefore a veritable alternative to internal $R \& D$ is the adoption of licensing of external technology. Researchers 
indicate that it could offer the advantage of keeping up with new technology and enhancing access of new product to the market (Kotabe, Sahay, and Aulakh 1996).

There is an ever increasing need for local enterprises to consider options for being resilient and competitive amidst burgeoning globalisation with the attendant technological-innovation led competition (Siddharthan and Narayanan 2018; Ghosh and Roy 2018). Expert discussions in the literature opine that foreign technology adoption helps in product innovation and market entry (FAO, 2019). Licensing foreign technology assists local enterprises in the reduction of the intensity of local enterprises R\&D (Ghosh and Roy 2018). Technology plays a major role in contemporary product and service patronage by the market (Kotabe, Sahay, and Aulakh 1996). Hence avoidance of technology is tantamount to innovation avoidance, which can facilitate enterprise demise (Jiang et al. 2014). Product innovation is costly given the technology requirements. Therefore, the survival of local enterprises in a dynamically competitive world of business is to look for alternative technology to keep pace with global product trends (Rahman, Yaacob, and Radzi 2016). One of such alternative is licensing of foreign technology (Atuahene-Gima and Patterson 1993). Therefore, the objective of this paper is to examine the relationship between licensing of foreign technology and new product innovation. Hence, the research question is whether licensing of foreign technology is related to new product innovation. Extant research about the role of technology licensing on product innovation has concentrated on a country and regional level studies. This research makes contribution to existing research by engaging on a global study that uses data from fifty (50) different countries of the world.

The remaining portion of this paper is organised as follows. After this introduction, the paper presents a theoretical framework on innovation. This is followed by a review of the literature. Soon after the literature, the paper presents the hypotheses development section. This is followed by the method and result section. Thereafter, the paper ends with conclusion and recommendations.

\section{Theoretical Framework}

DISRUPTIVE INNOVATION THEORY

The disruptive innovation theory has enthralled the business management sphere. It is considered to be one such idea that is most persua- 
sive in the globalised business world (King and Baatartogtokh 2015). In his book The Innovator's Dilemma published in 1997, Christensen (2003) elucidated on the failure of renowned and exceptionally well managed organisations indicating that even the best of the managers are continuously at risk of ignoring competitors who are capable of introducing disruptive technologies. Disruptive technologies are considered to be those that add varied value and benefits to the general ones that are considered to be inferior when compared to mainstream technologies that enhance performance to targeted customers. As a consequence disruptive technologies have other features, considered to be cheaper, simpler, smaller, etc.; and may be used by new entrants in the market place and may be utilised at the lower end or in a new and niche markets (Hang and Chen 2008). While the term disruptive innovation may be used synonymously with disruptive technologies, Christensen and Raynor (2013) preferred to use the former because the application of the theory is not only used for products that are highly technological but can also be used for business model innovation. The disruptive innovation concept can be categorised as sustaining or disruptive. Sustaining innovations are implemented to sustain the firm's growth in the market (Hagedoorn and Cloodt 2003). In order to achieve continuous growth, a company needs to improve service/product features to appeal to the external users. Further, sustaining innovations can help improve the product given in its initial performance dimension designed to achieve specific customer value, in an incremental manner. While disruptive innovations are those that may disrupt even large firms with various major resources such as Research and Development facilities, highly skilled human capital, and other formidable absorptive capabilities (Hagedoorn and Cloodt 2003). To note disruptive innovations usually starts with inferior performing products, however when improvements are implemented their performance becomes much more superior when compared with their current counterparts, and end up replacing them.

\section{ABSORPTIVE CAPACITY THEORY}

The absorptive capacity theory was initially expounded by Cohen and Levinthal (1990) in the business management and organizational science domain. They used the theory as a construct at the company level. They defined absorptive capacity as the 'ability to recognize the value of new information, assimilate it, and apply it to commercial ends' (Cohen and Levinthal 1990, 128). The new information may be gathered from the in- 
ternal units in the firm or may also be from the outside of the formal innovating units (research and development) such as the manufacturing, marketing etc. The absorption capacity is not all about a firm acquiring and assimilating information, but it is also about the ability to exploit it for the advantage of the firm. It is about the ability for a company to acquire known knowledge that can be assimilated with new knowledge thereby use new knowledge for the benefit of the entire organization. As such knowledge utilization becomes important factor in predicting the benefits that result in developing innovative products or services. Researches done indicate that firms that are focused in conducting research and development are able to use information from the external sources (Mowery and Nathan 1983). Denoting that absorptive capacity is essentially the results the firm's research benefits (Cohen and Levinthal 1990). With current increased competition, many firms are increasingly competing based on the results of the research sophistication along with their available vast and integrated networks (Roijakkers and Hagedoorn 2006). Many multinational for example, apply their dispersed vast knowledge gathered from their subsidiaries and operations scattered globally (Chesbrough 2003). They use this integrated accumulated knowledge from the entire worldwide innovation networks to achieve competitive advantage (Bartlett and Ghoshal 1989). As they interconnect and leverage on the knowledge gathered from their various operational subsidiaries, they are able to develop, implement new innovative products as efficient as possible while at the same time responding and meeting their local client needs (Subramaniam and Venkatraman 2001). It is also indicated that absorptive capacity may develop from the manufacturing processes. It is suggested that the original measure for absorptive capacity is 'Research and Development ( R\&D) intensity, which is articulated as company unit-funded R\&D cost calculated as percentage of firm's unit sales and transfers (Cohen and Levinthal 1990).

Absorptive Capacity is an important theory particularly in information systems (Is) and knowledge management research (Addorisio et al. 2014). Many organizations spend large amounts of monies to services, infrastructure, software, and capacitating their human resources to develop absorptive and other related capabilities to use with newly acquired knowledge. As a result they are able to achieve and maintain a continuous growth and competitive advantage (Armstrong and Sambamurthy 1999).

Subsequently, Zahra and George (2002) reviewed and reconceptualise the absorption capacity concept as a capability that is dynamic relative to 
the creation of knowledge and how it is utilized to enhance and enable the firm to gain and maintain competitive advantage. In their conceptualization, two different absorptive capacities were identified, namely; potential absorptive capacity as well as the realized absorptive capacity. They indicated that potential absorptive capacity enables the firm to be receptive to gather and integrate the acquired external knowledge. Whereas realized absorptive capacity enables the firm to have transformation as well as exploitation capabilities. Transformation capabilities are those that are enabling the firm to develop practises that facilitate the combination of current known knowledge, newly acquired and integrated or assimilated knowledge. While exploitation capability referred to that which the organisation possesses in the application of acquired knowledge in those products or services resulting in the financial benefit for the organization.

\section{Literature Review}

\section{PRODUCT INNOVATION}

The new product development strategy plays a critical and fundamental role in the long term survival and competitiveness of any company. To be successful in the ever changing, competitive and global market; firms need to be innovative and explore new ideas in order to design and create new products (Martin 2009). The performance of many firms becomes unsatisfactory if they continue to focus in exploiting redundant past ideas, such as production processing and cost-cutting (Martin 2009). It is suggested that product innovation enables a firms to use knew knowledge to create new innovative products to develop and achieve a sustainable competitive advantage in the market environment (Shan and Jolly 2013; Defélix, Mazzilli, and Gosselin 2015). There are different types of company innovations that are vital to the process of creating new, enhanced capabilities or increased product use (Drucker 1985). Product innovation is vital as it is at the core of new product strategy. The introduction of new product is not only important in securing future profit growth but also in the corporate share price performance (Issah and $\mathrm{Ng}$ menipuo 2015). To be successful in implementing a new product strategy, a business needs to be competent and be able to invest substantial amount of resources in its research and development function, product design, marketing research and related departments. The firm needs to adopt an innovative culture. 
There are various types of innovation that a company may adopt, including: new products innovation, new production methods, identified new distribution and supply channels, market development, and creative ways to structure the organisation (Schumpeter 1934). Product innovation is thus referred to as the way new products or services are introduced in order to satisfy the identified needs of the market or external user (Damanpour 2017). It is also defined as the process of conceiving and implementing new products, including some of those activities such as $\mathrm{R} \& \mathrm{D}$, technical design and related marketing of new product and services. New products may include those that are completely new, additional new lines, and those that have modified ( $\mathrm{Li}$ and Atuahene-Gima 2001). Product innovation can be regarded as important factor in the medium- to long-term survival of firms (Pérez-Luño, Gopalakrishnan, and Valle-Cabrera 2014). When the firm adopts a product innovation strategy it enable the company to retain and expand its offerings to the fierce competitive markets (Baker and Sinkula 2009). Without adopting the product innovation strategy a firm may find it difficult to achieve its long term success. A firm with a product innovation strategy is able have capacity to withstand markets with fast changing consumer requirements and having highly technological advancements (Phromket, Prajudtasri, and Phangkhot 2010).

\section{INNOVATION PROCESS}

Literature indicates that product innovation and process innovation are related and are supplementary. Process innovation is regarded as the implementation of a new improved production and/or delivery methods (OECD 2005). The improvement may among other changes include techniques, equipment and related software. It may also be implemented to decrease factors such as unit cost of production, quality enhancement and new delivery methods. The innovation process may be regarded as transformational process in the innovation developmental framework. It emphasises re-innovation/re-invention process that emphasises the improvement of current process through cost reduction and performance of the entire production cycle (OECD 2005).

\section{COMPANY PERFORMANCE}

Firm performance is regarded as a business construct consisting of various dimensions that can be used to determine companies' achievement and success (Naser, Karbhari, and Mokhtar 2004; Yeung, Lee, and Chan 
2003). In the current competitive markets, conducting performance evaluation is considered to be a vital element to ensure that the developed and implemented business strategies are effective. Performance evaluation can thus be regarded as the process that is used to quantify if the production systems are efficient and also effective (Singh 2008). Various scholars have identified a number of measurements that can be used for organizational performance, and the four main dimensions are; the innovative performance, production performance, market performance and financial performance (Hagedoorn and Cloodt 2003; Yilmaz, Alpkan, and Ergun 2005). Innovation performance is defined as the market rewards that the firm derives from newly introduced products or services in the market as measured in terms of contribution to firm's sales income or its profits (Bakar and Ahmad 2010). Prajogo and Ahmed (2006) indicate that innovation performance is function of both product and process innovation measured on innovation output, rapidity of innovation, degree of innovativeness and the 'speed' to market. Considering operational performance, it can be measured based on numerous performance dimensional aspects including internal operational performance that may be relative to firm's product quality, its efficiency and productivity (Naser, Karbhari, and Mokhtar 2004). Further, firm performance may also be measured based on financial perspective. In today's customer-driven market environment, marketing competence resulting in capturing high market share is vital to achieve better financial results (Li 2000). Continuous sales revenues growth and decreasing marginal unit costs contribute to a high increase in the firm's overall profitability and also to the increase of share price (Venkatraman and Prescott 1990; Wang and Wei 2005).

\section{PRODUCT INNOVATION AND FIRM PERFORMANCE}

The relationship of product innovation and how it impacts on firm performance remains controversial and unresolved. The research work aimed at establishing the link between two business concepts remains complex and diverse. Empirical results in this regard are mixed. It has been acknowledged that firms that process innovating competences may often not achieve positive financial results from product innovation (Teece 1986). Conversely, it has been found that over two-thirds of research conducted show a relationship between product innovation and firm performance, while the rest indicate that there is a negative relationship or none at all (Capon, Farley, and Hoenig 1990). 
The results of the research conducted to investigate the relationship between company's performances and how it relates to innovation and research have revealed that a company is inclined to develop new innovations based on the importance to achieve a higher competitive advantage in the market (McAdam and Keogh 2004). It was further concluded that innovations have an impact on the firms' profits (Favre et al. 2000). Firms that have strong innovative culture were found to be more profitable and achieving high growth rate when compared to those who are not (Diederen, van Meijl, and Wolters 2002).

Various scholars indicate that innovation through the introduction of new product enhances long-term financial performance (Cheng, Lai, and $\mathrm{Wu}$ 2010; Pauwels at al. 2004). That is, companies that have adopted the innovative culture are able to develop products preferred by users and have favourable brand image enabling to attain higher market share, charge premium prices contributing to increased profit margins (Hanaysha, Hilman and Hasmini Abdul-Ghani 2014). Innovation is critical to the firm to achieve dominance in the market place and achieving high profitability (Cheng, Lai, and $\mathrm{Wu}$ 2010). Generally, innovation has high impact on the company's performance because it helps the firm to achieve improved market position and demonstrate attainment of competitive edge and superior performance level (Walker 2004). Research conducted indicate that companies which are more innovative are also concerned more with management techniques (Baldwin and Johnson 1996), thus contributing to the objective of achieving sustainable higher performance levels (Hult, Hurley, and Knight 2004). Product innovation in particular enables a firm to sustain competitive advantage, combat competition and create barriers of entry. It also enables these firms to dominate and become market leader, establish new distribution channels, and target new customers. Innovation provides firms with creative methods of doing business better than their competitors (Ahuja 2000). It was also concluded that when the firms is innovative it can significantly impact on the company's productivity knowledge capital (Hollenstein and Arvantis 2002).

Various scholars concur that product and process innovations play a vital supplementary role in impacting on the performance of an organisation. The two dimensions are managed they the firm can improve their competitiveness relative to its competitors, achieve high profitability, and improved market share (Cheng, Lai, and Wu 2010). Product innovation influences the firm to gain competitive edge through technology inno- 
vation, and as a result improving the product or service performance. Conversely, process innovations influences production efficiencies particularly when the firm implements newly adopted effective methods of producing current products or services (Evangelista and Vezzani 2010).

Notably, process innovation has a higher impact on the production cost, however its influence to the firm's growth and market share may be minimum when compared to product innovation (Cheng, Lai, and Wu 2010). Various empirical studies conducted conclude that for example, quality process and innovation positively impact on the firm's performance. It is further concluded that when Total Quality Management (TQM) is integrated with innovation there is a positive impact on company's profitability and market share (Kumar and Sharma 2017; Leavengood, Anderson, and Daim 2014).

\section{Hypothesis Development}

\section{TECHNOLOGY LICENSING, PRODUCT INNOVATION AND MARKET ACCESS}

There is an increase in the adoption of external technology licensing in creating new products and services, which serves as an alternative to researching and developing internal products and services (AtuaheneGima and Patterson 1993; Markman et al. 2005). The adoption of external technology licensing as an alternative to new product research and development is thus a management behaviour approach in responding to both internal and external competitive stimuli (Atuahene-Gima 1992). This serves two purposes namely to keep up with emerging technology, which would ordinary be costly for emerging enterprises and to gain market access with a new product (Ulas 2007). It has thus been opined that technology licensing enhances market access of new products (Boden and Goldstein 2018). Accordingly, many extant researches have been trying to examine if new technology product innovation does affect product performance in the market (Atuahene-Gima and Patterson 1993). But these previous researches have either concentrated on a country study or on a regional study. For instance, very recently (Wu, Ma, and Liu 2019) examined whether technology capability enhances new product performance in the market in large Chinese cities. Our paper contributes a nuance to existing research by examining this concept at a global level using a global data that covers fifty different countries.

We therefore hypothesise as follows, hypothesis 1: 
но There is no significant relationship between technology licensing and new product innovation and market access.

$\mathrm{H} 1$ there is a significant relationship between technology licensing and new product innovation and market access

\section{WEBSITE AND PRODUCT DEVELOPMENT AND MARKET ACCESS}

In many companies across the world, enterprise website has constituted a veritable platform for increasing business undertakings (Kuivalainen 2009). In their research, Kuivalainen (2009) unravelled the effect of enterprise website on enterprise product development. They find that web site in a service company helps to improve customer experience and attendant patronage. Supportive research does confirm that enterprise communication strategy affects new product performance (Lee and O'Connor 2003). Current researches on persuasive power of website confirm that website facilitates positive consumer patronage and purchasing behaviour (Hamid et al. 2019; Tang, Yang, and Shao 2019).

We therefore hypothesise as follows, hypothesis 2:

но There is no significant relationship between enterprise website development and new product innovation and market access

$\mathrm{H} 1$ There is a significant relationship between enterprise website development and new product innovation and market access.

\section{Method and Results}

Data were collected from the World Bank archive of Global Enterprise Survey (World Bank 2019). Given that the previous literature had highlighted the important contribution of enterprise foreign technology licensing and enterprise website ownership on product innovation (Atuahene-Gima 1992; Kuivalainen 2009), the paper thus extracted these three variables from the aforementioned World Bank's data archive for the first fifty countries in the global enterprise survey data (after eliminating the countries with incomplete data within this first range of fifty countries). Data were analysed quantitatively using the Structural Equation Model (SEM). This was justified on the ground that data were stationery. Hence the two variables namely foreign technology licensing and enterprise website ownership were the independent variables, whilst the percentage of new products in the market served as the depended variable, to show how foreign technology licensing and web site ownership by enterprises can after the dependent variable. 
TABLE 1 Result of Structural Equation Model (SEM) for Foreign Technology Licensing, Enterprise Website Ownership and Percentage of New Products in the Market

\begin{tabular}{lrrrrrr}
\hline Item & $(1)$ & $(2)$ & $(3)$ & $(4)$ & $(5)$ & $(6)$ \\
\hline Licensed foreign tech. & 0.571 & 0.232 & 2.460 & 0.014 & 0.116 & 1.026 \\
Website & -0.034 & 0.081 & -0.420 & 0.673 & -0.192 & 0.124 \\
Constant & 61.850 & 5.174 & 11.950 & 0.000 & 51.708 & 71.992 \\
Mean (licensed tech.) & 13.648 & 0.961 & 14.200 & 0.000 & 11.765 & 15.531 \\
Mean (website) & 47.226 & 2.764 & 17.090 & 0.000 & 41.809 & 52.643 \\
Var (new product, & 124.477 & 24.895 & & & 84.111 & 184.218 \\
new in mark) & & & & & & \\
Var (licensed tech.) & 46.169 & 9.233 & & & 31.197 & 68.327 \\
Var (website) & 381.981 & 76.396 & & & 258.108 & 565.305 \\
Cov (licensed tech, & 1.634 & 18.782 & 0.090 & 0.931 & -35.178 & 38.447 \\
website) & & & & & & \\
\hline
\end{tabular}

Notes Column headings are as follows: (1) coefficient, (2) orm standard error, (3) $Z$, (4) $p$ > IzI, (5-6) 95\% confidence interval.

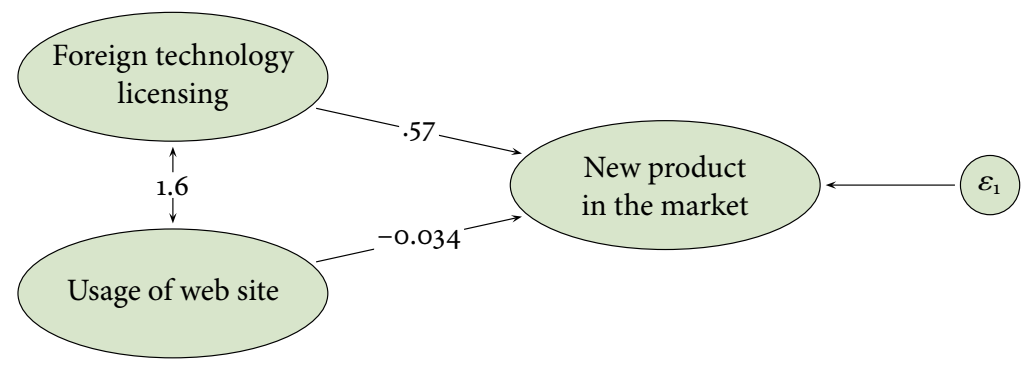

FIGURE 1 Structural Equation Model Graph

\section{Discussion and Conclusion}

Results depicted in table 1 one and in figure 1 show that the number of companies amongst the fifty sample, which are adopting the licensing of foreign technology has a low mean of 13.6 compared to the mean of companies using web with a higher mean of 47.2. This means that more global companies are using web site technology to promote innovation of products, whilst little number of companies is using licensed foreign technology. Furthermore, the number of companies using web site technology tends to vary more than the number of companies using licensed foreign technology at 382 and 46 for licensed foreign technology and web site usage respectively. Regarding whether there is a covariance between 
the independent variables (licensed foreign technology and web site usage), the analysis in table 1 show a $p$-value of 0.93 , which is higher than the alpha level of $0.05(5 \%)$. This means there is no covariance between the two independent variables. Importantly, the SEM in table 1 vshow that the number of companies with licensed foreign technology is positively and significantly related to innovation of a new product in the market at a $p$-value of 0.014 , which is lower than the alpha of 0.05 . Therefore the null hypothesis 1 is rejected in favour of the alternative hypothesis 1 , which suggests that foreign technology licensing has a positive and significant effect on new product innovation. However, the usage of web site shows no significant relationship with innovation of a new product in the market at a $p$-value of 0.67 which is higher than the alpha level of 0.05 . Accordingly, the null hypothesis 2 is accepted, which suggests there is no significant relationship between web site usage and new product innovation.

This result is consistent with prior literature conducted at country or regional studies, which show that licensed foreign technology, can enhance new product innovation into the market. But this research has proven this assertion at a global level by examining companies from fifty different countries. The findings of this research is consistent with previous research conducted at a country level, wherein technology adoptive capacity was found to be significantly related to new product development (Chen and Chang 2019; Lim and Kim 2018).

The practical implication is that companies can achieve the same objective of new product innovation by saving on internal $R \& D$ cost to adopt foreign technology licensing (United Nations and African Union 2014). This also has an added advantage of showcasing the latest technology that is in vogue in international market, which ordinarily an average enterprise may not be able to afford the cost (Atuahene-Gima 1992).

The findings of this research hold particular implication for developing countries - mostly for African countries that have the lowest rate of productivity and competitiveness compared to other continents in the world. Since technology drives innovation, production of new products and the attendant competiveness, African countries and other developing countries with low capacity to initiate new technology for production may adopt technology licensing to drive innovation and new product development in Africa. There is the likelihood that if this strategy of technology adoption is sustained, developing nations such as Africa may experience an upward positive trend from its lowest productivity and com- 
petitive position. This proposition thus calls for further research in two fronts namely to increase the number of countries used from fifty in this research to greater number and for other research to create a pool of developing countries and conduct and empirical examination of how technology licensing may improve innovation, new product development and competitiveness in developing countries.

\section{References}

Addorisio, M., S. Gao, W. Yeoh, and S. F. Wong. 2014. 'Critical Analysis of the Use of Absorptive Capacity Theory in Is Research.' In Proceedings of the 5th International Conference on Information Systems, 1-15. Auckland: Association for Information Systems.

Ahuja, G. 2000. 'Collaboration Networks, Structural Holes and Innovation: A Longitudinal Study'. Administrative Science Quarterly 45:42555 .

Armstrong, C. P., and V. Sambamurthy. 1999. 'Information Technology Assimilation in Firms: The Influence of Senior Leadership and IT Infrastructures.' Information Systems Research 10 (4): 304-27.

Atuahene-Gima, K. 1992. 'Inward Technology Licensing as an Alternative to Internal R\&D in New Product Development: A Conceptual Framework.' Journal of Product Innovation Management 9 (2): 156-67.

Atuahene-Gima, K., and P. Patterson. 1993. 'Managerial Perceptions of Technology Licensing as an Alternative to Internal $\mathrm{R} \& \mathrm{D}$ in New Product Development: An Empirical Investigation.' R\&D Management 23 (4): $327-36$.

Bakar, L. J. A., and H. Ahmad. 2010. 'Assessing the Relationship between Firm Resources and Product Innovation Performance: A ResourceBased View. Business Process Management Journal 16 (3): 420-35.

Baker, W. E., and J. M. Sinkula. 2002. 'Market Orientation, Learning Orientation and Product Innovation: Delving into the Organization's Black Box.' Journal of Market-Focused Management 5 (1): 5-23.

Baldwin, J., and J. Johnson. 1996. 'Business Strategies in More and Less Innovative Firms in Canada.' Research Policy 25 (5): 785-804.

Bartlett, C., and S. Ghoshal. 1989. Managing Cross Borders. Boston, MA: Harvard Business School Press.

Boden, M., and J. Goldstein. 2018. 'Licensing Medical Devices to Manufacturers/Partnering With Large Companies.' In Medical Innovation: Concept to Commercialization, edited by K. E. Behrns, B. Gingles, and M. G. Sarr, 51-63. Cambridge, M A: Academic Press.

Capon, N., J. U. Farley, and S. Hoenig. 1990. 'Determinants of Financial Performance: A Meta-Analysis.' Management Science 36 (10): 1143-59. 
Chen, M. N., and Y. C. Chang. 2019. 'Absorptive Capacity, Appropriability Depth and New Product Development in Taiwanese Service Firms.' Asian Journal of Technology Innovation 27 (1): 108-33.

Cheng, C., M. Lai, and W. Wu. 2010. 'Exploring the Impact of Innovation Strategy on R\&D Employees' Job Satisfaction: A Mathematical Model and Empirical Research.' Technovation 30 (9): 459-70.

Chesbrough, H. W. 2003. Open Innovation: The New Imperative for Creating and Profiting From Technology. Boston, MA: Harvard Business School Press.

Christensen, C. M. 2003. The Innovator's Dilemma: When New Technologies Cause Great Firms to Fail. New York: HarperCollins.

Christensen, M. C., and M. E. Raynor. 2013. The Innovator's Solution: Creating and Sustaining Successful Growth. Boston, M A: Harvard Business School Press.

Cohen, W. M., and D. A. Levinthal. 1990. 'Absorptive Capacity: A New Perspective on Learning and Innovation.' Administrative Science Quarterly 35 (1): $128-52$.

Damanpour, F. 2017. 'Organizational Innovation.' Oxford Research Encyclopedia of Business and Management. https://doi.org/10.1093/acrefore/ 9780190224851.013.19

Defélix, C., I. Mazzilli, and A. Gosselin. 2015. 'Articuler les politiques de GRH et les stratégies d'innovation: des modèles à l'épreuve des faits.' Revue de Gestion des Ressources Humaines 2 (1): 60-72.

Diederen, P., H. van Meijl, and A. Wolters. 2002. 'Innovation and farm Performance.' In Innovation and Firm Performance, edited by A. Kleinknecht and D. Mohnen, 73-85. London: Palgrave.

Drucker, P. F. 1985. 'The Discipline of Innovation.' Harvard Business Review 63 (3): $67-72$.

Evangelista, R., and A. Vezzani. 2010. 'The Economic Impact of Technological and Organizational Innovations: A Firm-Level Analysis.' Research Policy 39 (10): 1253-63.

Evangelista, R., T. Sandven, G. Sirilli, and K. Smith. 1998. 'Measuring Innovation in European Industry'. International Journal of the Economics of Business 5 (3): 311-33.

Favre, F., S. Negassi, and E. Pfister. 200o. 'The effect of Spillovers and Government Subsidies on R\&D, International R\&D Cooperation and Profit.' In Innovation and Firm Performance, edited by A. Kleinknecht and P. Mohnen, 201-24. London: Palgrave.

Ghosh, M., and R. P. Roy. 2018. 'F DI, Technology Imports and R \& D in Indian Manufacturing: Revisited.' In Globalisation of Technology, edited by N. S. Siddharthan and K. Narayanan, 127-49. Singapore: Springer.

Hagedoorn, J., and M. Cloodt. 2003. 'Measuring Innovative Performance: 
Is There an Advantage in Using Multiple Indicators?' Reasearch Policy 32 (8): 1365-79.

Hamid, N. A., C. H. Cheun, N. H. Abdullah, M. F. Ahmad, and Y. Ngadiman. 2019. 'Does Persuasive E-commerce Website Influence Users' Acceptance and Online Buying Behaviour? The Findings of the Largest E-commerce Website in Malaysia.' In ICT for a Better Life and a Better World, edited by Y. Baghdadi and A. Harfouche, 263-79. Lecture Notes in Information Systems and Organisation 30. Cham: Springer.

Hanaysha, J., H. Hilman, and N. Hasmini Abdul-Ghani. 2014. 'Direct and Indirect Effects of Product Innovation and Product Quality on Brand Image: Empirical Evidence from Automotive Industry.' International Journal of Scientific and Research Publications 4 (1): 2250-3153.

Hang, C. C., and J. Chen. 2008. 'Disruptive Innovation: An Appropriate Innovation Approach for Developing Countries.' E TM Internal Report, no. 1/o8:1-34.

Hagedoorn, J., and M. Cloodt. 2003. 'Measuring Innovative Performance: Is There an Advantage in Using Multiple Indicators?' Research Policy 32:1365-79.

Hollenstein, H., and S. Arvantis. 2002. 'The Impact of Spill Overs and Knowledge Heterogeneity Confirm Performance: Evidence from Swiss Manufacturing.' In Innovation and Firm Performance: Econometric Explorations of Survey Data, edited by A. Kleinknecht and P. Mohnen, 225-52. Basingstoke: Palgrave Macmillian.

Hult, G. T. M., R. F. Hurley, and G. A. Knight. 2004. 'Innovativeness: Its Antecedents and Impact on Business Performance.' Industrial Marketing Management 33 (3): 429-38.

Issah, O., and I. M. Ngmenipuo. 2015. 'An Empirical Study of the Relationship between Profitability Ratios and Market Share Prices of Publicly Traded Banking Financial Institutions in Ghana.' International Journal of Economics, Commerce and Management United Kingdom 3 (12): 2742.

Jiang, J., J. McPherson, A. Wittman, S. Limarta, T. H. Wang, J. Pessey, and P. Tippayasawate. 2014. 'How Businesses Fail in Managing Technology: A Review of the literature.' In Proceedings of PICMET'14 Conference, 58597. New York: IEEE.

Kotabe, M., A. Sahay, and P. S. Aulakh. 1996. 'Emerging Role of Technology Licensing in the Development of Global Product Strategy' Journal of Marketing 6o (1): 73-88.

King, A. A., and B. Baatartogtokh. 2015. 'How Useful Is the Theory of Disruptive Innovation?' MIT Sloan Management Review, 15 September. https://sloanreview.mit.edu/article/how-useful-is-the-theory-of -disruptive-innovation 
Kuivalainen, O. 2009. 'Complementary Role of Website in Business Model Development.' In Emergent Strategies for E-Business Processes, Services and Implications: Advancing Corporate Frameworks, edited by I. Lee, 136-54. Hershey, PA: I I Global.

Kumar, V., and R. R. K. Sharma. 2017. 'Relating Management ProblemSolving Styles of Leaders to TQM Focus: An Empirical Study' The TQM Journal 29 (2): 218-39.

Leavengood, S., T. R. Anderson, and T. U. Daim. 2014. 'Exploring Linkage of Quality Management to Innovation.' Total Quality Management and Business Excellence 25 (9-10): 1126-40.

Lee, Y., and G. Colarelli O'Connor. 2003. 'The Impact of Communication Strategy on Launching New Products.' Journal of Product Innovation Management 20 (1): 4-21.

Li, L. 200o. 'An Analysis of Sources of Competitiveness and Performance of Chinese Manufacturers.' International Journal of Operations and Production Management 20 (3-4): 299-315.

Lim, J., and B. K. Kim. 2018. 'The Effects of Entrepreneurship Orientation and Absorptive Capacity on Corporate Performance: Focusing on Mediating Effects of Product Innovation Performance.' Journal of Korea Technology Innovation Society 21 (4): 1536-76.

Markman, G. D., P. T. Gianiodis, P. H. Phan, and D. B. Balkin. 2005. 'Innovation Speed: Transferring University Technology to Market.' Research Policy 34 (7): 1058-75.

Martin, R. 2009. The Design of Business: Why Design Thinking is the Next Competitive Advantage. Boston, MA: Harvard Business Press.

McAdam, R., and K. Keogh. 2004. 'Transitioning towards Creativity and Innovation Measurement in SM Es.' Creativity and Innovation Management 13 (2): 126-41.

Mowery, D. C., and R. Nathan. 1989. Technology and the Pursuit of Economic Growth. New York: Cambridge University Press.

Naser, K., Y. Karbhari, and M. Z. Mokhtar. 2004. 'Impact of Iso 9000 Registration on Company Performance: Evidence from Malaysia.' Managerial Auditing Journal 19 (4): 509-16.

OECD. 2005. Oslo Manual: Proposed Guidelines for Collecting and Interpreting Technological Innovation Data. Paris: OECD.

Pauwels, K., J. Silva-Risso, S. Srinivasan, and D. M. Hanssens. N.d. 'New Products, Sales Promotions, and Firm Value: The Case of the Automobile Industry.' Journal of Marketing 68 (4): 142-56.

Pérez-Luño, A., S. Gopalakrishnan, and R. Valle-Cabrera. 2014. 'Innovation and Performance: The Role of Environmental Dynamism on the Success of Innovation Choices.' IE EE Transactions on Engineering Management 61 (3): 499-510. 
Phromket, C., P. Prajudtasri, and D. Phangkhot. 2010. 'The Influences of Product Innovation Development on Performance: An Empirical Study of Electronics and Electrical Equipment Industry in Thailand.' Journal of Academy of Business and Economics 10 (1): 78-88.

Prajogo, D. I., and P. K. Ahmed. 2006. 'Relationships between Innovation Stimulus, Innovation Capacity and Innovation Performance.' $R \& D$ Management 36 (5): 499-515.

Rahman, N. A., Z. Yaacob, and R. M. Radzi. 2016. 'An Overview of Technological Innovation on sme Survival: A Conceptual Paper.' Procedia: Social and Behavioral Sciences 224:508-15.

Roijakkers N., and J. Hagedoorn. 2006. 'Inter-Firm R\&D Partnering in Pharmaceutical Biotechnology since 1975: Trends, Patterns, and Networks.' Research Policy 35 (1): 431-46.

Salunke, S., J. Weerawardena, and J. R. McColl-Kennedy. 2019. 'The Central Role of Knowledge Integration Capability in Service InnovationBased Competitive Strategy'. Industrial Marketing Management 76:14456.

Schuhmacher, A., O. Gassmann, N. McCracken, and M. Hinder. 2018. 'Open Innovation and External Sources of Innovation: An Opportunity to Fuel the R\&D Pipeline and Enhance Decision Making?' Journal of Translational Medicine 16 (1): 119. https://doi.org/10.1186/s12967-0181499-2

Schumpeter, J. A. 1934. The Theory of Economic Development: An Inquiry into Profits, Capital, Credit, Interest, and the Business Cycle. New Brunswick, NJ: Transaction Publishers.

Shan, J., and D. R. Jolly. 2013. 'Technological Innovation Capabilities, Product Strategy, and Firm Performance: The Electronics Industry in China.' Canadian Journal of Administrative Sciences 30 (3): 159-72.

Siddharthan, N. S, and K. Narayanan. 2018. Globalisation of Technology. Singapore: Springer.

Singh, P. 2008. 'Empirical Assessment of iso 9000 Related Management Practices and Performance Relationships.' International Journal of Production Economics 113 (1): 40-59.

Subramaniam, M., and N. Venkatraman. 2001. 'Determinants of Transnational New Product Development Capability: Testing the Influence of Transferring and Deploying Tacit Overseas Knowledge.' Strategic Management Journal 22 (4): 359-78.

Tang, Y., Y. T. Yang, and Y. F. Shao. 2019. 'Acceptance of Online Medical Websites: An Empirical Study in China.' International Journal of Environmental Research and Public Health 16 (6): 943. https://doi.org/10 .3390/ijerph16060943.

Teece, D. J. 1986. 'Profiting from Technological Innovation: Implications 
for Integration, Collaboration, Licensing and Public Policy.' Research Policy 15 (6): 285-305.

Ulas, D. 2007. 'Eu Market Access: The Way of Licensed Warehousing System for Turkish Food Producers and Exporters.' Poster paper prepared for presentation at the 105th EA A E Seminar International Market and International Trade of Quality Food Products, Bologna, 8-10 March.

United Nations and African Union. 2014. 'Innovation and Technology Transfer for Enhanced Productivity and Competitiveness in Africa.' https://www.uneca.org/sites/default/files/uploadeddocuments/CoM/ com2014/com2014innovation_and_technlogy_transfer_for_enhanced _productivity_and_connectiveness_in_africa-english.pdf

Venkatraman, N., and J. E. Prescott. 1990. 'Environment Strategy Coalignment: An Empirical Test of its Performance Implications.' Strategic Management 11 (1): 1-23.

Walker, R. M. 2004. 'Innovation and Organizational Performance: Evidence and a Research Agenda.' Research Working Paper 2, Advanced Institute of Management, University of Hong Kong.

Wang, E. T. G., and H. L. Wei. 2005. 'The Importance of Market Orientation, Learning Orientation, and Quality Orientation Capabilities in TQM: An Example from Taiwanese Software Industry’ Total Quality Management 16 (10): 1161-77.

World Bank. 2019. 'Enterprise Survey.' https://www.enterprisesurveys.org/ en/data/exploretopics/innovation-and-technology

Wu, J., Z. Ma, and Z. Liu. 2019. 'The Moderated Mediating Effect of International Diversification, Technological Capability, and Market Orientation on Emerging Market Firms' New Product Performance.' Journal of Business Research 99:524-533.

Yeung, A. L., T. S. Lee, and L. Y. Chan. 2003. 'Senior Management Perspectives and Is 9000 Effectiveness: An Empirical Research.' International Journal of Production Research 41 (3): 545-69.

Yilmaz, C., L. Alpkan, and E. Ergun. 2005. 'Cultural Determinants of Customer and Learning Oriented Value Systems and Their Joint Effects on Firm Performance.' Journal of Business Research 58 (12): 1340-52.

Zahra, S., and G. George. 2002. 'Absorptive Capacity: A Review, Reconceptualization, and Extension.' Academy of Management Review 27 (2): 185-203. 